Uluslararası Mühendislik

Cilt/Volume:12 Sayı/Issue:1 Ocak/January 2020

\title{
Production and Characterization Of Ti-10Cr-3,33Co-3,33Egg Shelter Composite Materials Using By Powder Metallurgy
}

\author{
Ahmet Yönetken*1 iD, Günnur Peşmen² ${ }^{\text {iD }}$, Ayhan Erol ${ }^{3}$ iD \\ ${ }^{1}$ Afyon Kocatepe University, Faculty of Engineering, Electrical Engineering, ANS campus, 03200, Afyonkarahisar, TURKEY \\ ${ }^{2}$ Afyon Kocatepe University, Vocational College of Şuhut, 03830, Afyonkarahisar, TURKEY \\ ${ }^{2}$ Afyon Kocatepe University, Faculty of Technology, Metalurgy and Materials Engineering, ANS campus, O3200, Afyonkarahisar, TURKEY
}

\begin{abstract}
Titanium based intermetallic compounds are frequently used in the production of biomaterials. The behavior of titanium similar to bone mechanical properties causes the use of titanium as a biomaterial and preferred among the materials. It also makes its use attractive in industrial applications at high temperatures. TiCrCo intermetallics are known to be used together with $\mathrm{Ti}$ matrix materials to improve the properties of the group in addition to elements such as $\mathrm{Cr}$, especially $\mathrm{Ti}$, $\mathrm{Co}$, Mo and Fe in various application areas. This information is used frequently in the sintering process.

In this study, Ti-10Cr-3,33Co-3,33 egg shelter powders were prepared as a sample mixture. When the properties of the samples produced after sintering are examined, it shows the effects of Co on TiCr. 3.33\% Co additive was used in the composition of the composition and mechanical properties were determined in the produced samples. By looking at metallographic analysis, structural features were tried to be determined. The density of the produced samples was calculated, hardness and shear strength were determined. According to the results of the analysis, $3.33 \%$ Co composition and $3.71 \mathrm{gr} / \mathrm{cm}^{3} \mathrm{density}$, and $285.5 \mathrm{HV}$ hardness values at $1200^{\circ} \mathrm{C}$ were obtained..
\end{abstract}

\section{KeyWords}

"Sintering, intermetallic, Egg Shelter, Composite, High temperature." 


\section{Introduction}

In order to ensure sustainability in development, wastes must be recycled. Zero waste standards are a priority in environmental protection (Luengo et al. 2011). Agricultural waste utilization has made contributions to the many aspects of life such as its use as feedstock in the production of biobased products(Abdulrahman et al. 2014). Many agricultural wastes in the vicinity have been reported to be effective raw materials for the production of useful products (Xu et al.,2011;Boonpoke et al. 2013; Rashidi et al., 2012). Many researches on agricultural waste have primarily concerned with the use of energy potentials or its effective use (Ling and Teo, 2012; Surip et al., 2012; Zakaria et al. 2010; Peng et al., 2000). The eggshell is a protective barrier against the penetration of micro-organisms. The shell is a bioceramic composite material formed to protect the egg content (Neves, 1998;Boron 2004). Ceramics are widely used in cutting or cutting tools with high abrasion resistance (Yuhong et al., 2008; Upadhyaya and Bhaumik, 1998; Taheri and Mirhosseini, 2003). Electroless nickel plating is used especially in many industrial applications. The use of electroless nickel plating technique ensures homogeneous Ni distribution on the part to be coated in the bath. It plays an important role in preventing the non-uniform $\mathrm{Ni}$ coating in the electrolytic coating. Due to the increase in the sintering temperature of the samples, an increase in the ultrasonic properties except Poisson ratio was observed in both methods (Yönetken et al., 2019).

In the present work, Composites work Ti-10Cr-3,33Co-3,33 egg shelter powders were fabricated, microstructure was characterized, and mechanical properties such as hardness and density were studied. It was observed that the best properties the hardness $197,8 \mathrm{HV}$ were obtained for $1200^{\circ} \mathrm{C}$ composite.

\section{Preparation Of Sample}

\subsection{Material}

Metallic powder properties used in this study are given below. The $99.8 \%$ purity and particle size Ti powders less than $70 \mu \mathrm{m}$, were obtained from Sigma Aldrich. Cr powders having 99.9\% purity and a particle size less than $75 \mu \mathrm{m}$ from Sigma Aldrich were used. Co powders having 99.8\% purity and $2 \mu \mathrm{m}$ particle size from Sigma Aldrich were used. Composition of Ti-10Cr3,33Co-3,33 egg powders was prepared. Powder samples were shaped with $10 \mathrm{~g}$ circular uniaxial press. After weighing, the composition mixture was mixed in a mixer for 24 hours to ensure that the composition was homogeneous. The mixture was shaped by uniaxial cold hydraulic pressing using a high-strength steel mold. It was made under a pressure of 300 bar to compress all powder mixtures. Cold pressed samples were sintered at $900{ }^{\circ} \mathrm{C}, 1000{ }^{\circ} \mathrm{C}, 1100{ }^{\circ} \mathrm{C}, 1200{ }^{\circ} \mathrm{C}$, and $1300{ }^{\circ} \mathrm{C}$ for 2 hours in a conventional tube oven using an Argon gas atmosphere. After sintering, the samples were allowed to cool naturally under argon atmosphere in the oven. Micro hardness and shear strength of the samples were measured by METTEST-HT (Vickers) micro hardness tester, respectively. LEO $1430 \mathrm{VP}$ equipped with the Oxford EDX analyzer in TUAM, was used for SEM microstructure and EDX analysis as a scanning electron microscope.

The density changes of the composite samples produced in Ti-10Cr-3,33Co-3,33 egg powders were calculated using the sintering composite samples $(\mathrm{d}=\mathrm{m} / \mathrm{V})$ formula (Figure 1). The volume of sintered samples was measured by the Archimedes principle. All percentages and ratios were given in percent by weight.

\subsection{Experimental Results and Discussion}

In this section, the effect of chicken egg powders on the physical and mechanical properties of composite material production is investigated. The results of the samples produced in the study were characterized.

\subsection{Characterization of Specimens}

The composite samples prepared in the study were sintered in the traditional furnace at $900^{\circ} \mathrm{C}-1300^{\circ} \mathrm{C}$ and made ready for physical, mechanical, and metallographic analyzes. The density-temperature change curve is shown in Figure 1 . The highest sintered density is obtained at $3,95 \mathrm{~g} / \mathrm{cm}^{3}$ in $1200^{\circ} \mathrm{C}$. The lowest density of the composite samples is obtained as $3.52 \mathrm{~g} / \mathrm{cm}^{3}$ at $900^{\circ} \mathrm{C}$.

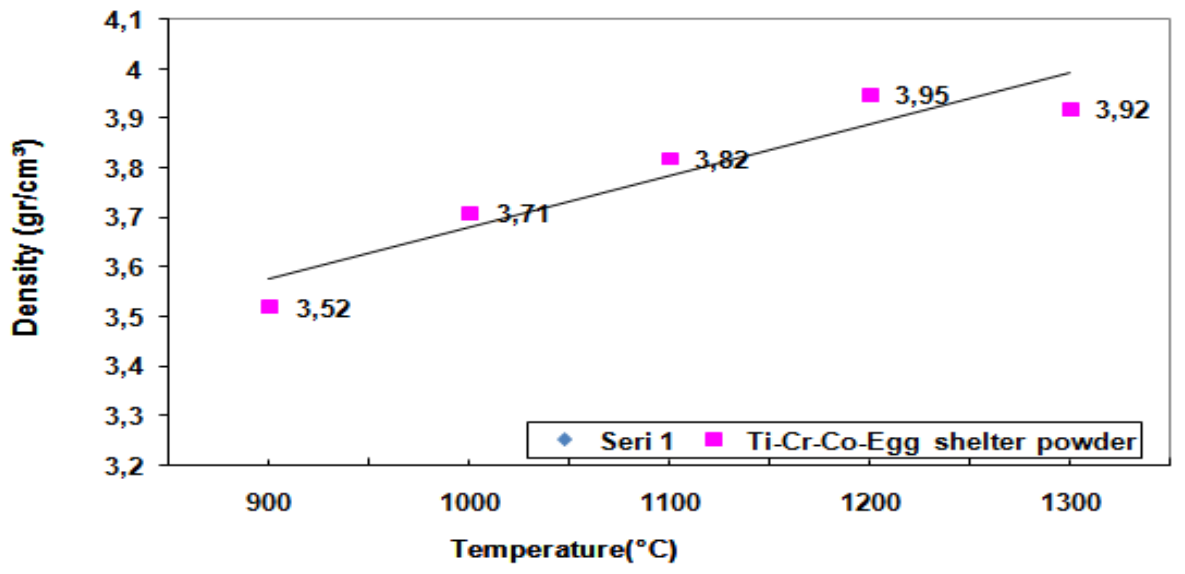

Figure 1. The temperature change with respect to composition at Ti-10Cr-3,33Co-3,33 egg shelter powders. 


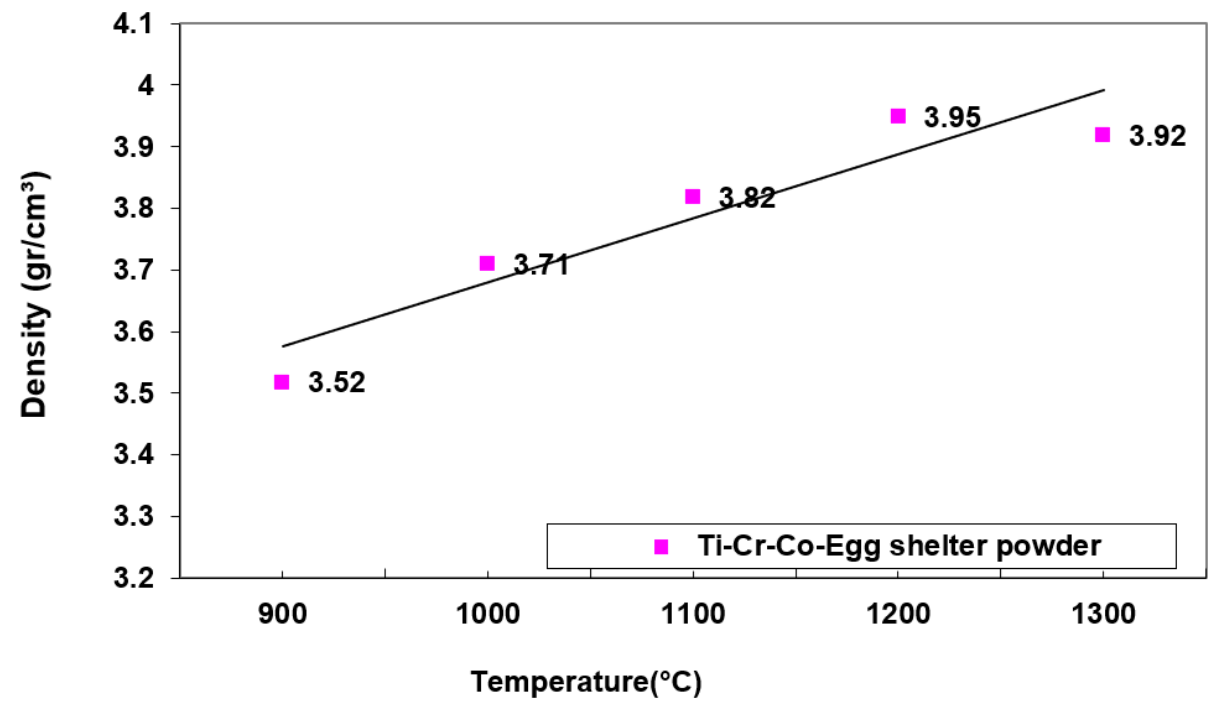

Figure 1 (cont.). The temperature change with respect to composition at Ti-10Cr-3,33Co-3,33 egg shelter powders.

The micro-hardness-temperature change diagram of the composite samples produced is given in Figure 2. Micro hardness values of the composite samples were produced in argon atmosphere using conventional sintering technique at $900^{\circ} \mathrm{C}-1300^{\circ} \mathrm{C}$. Accordingly, the highest micro hardness value of the composite samples produced by the powder metallurgy method is measured as $197,8 \mathrm{HV}$ at $1200^{\circ} \mathrm{C}$.

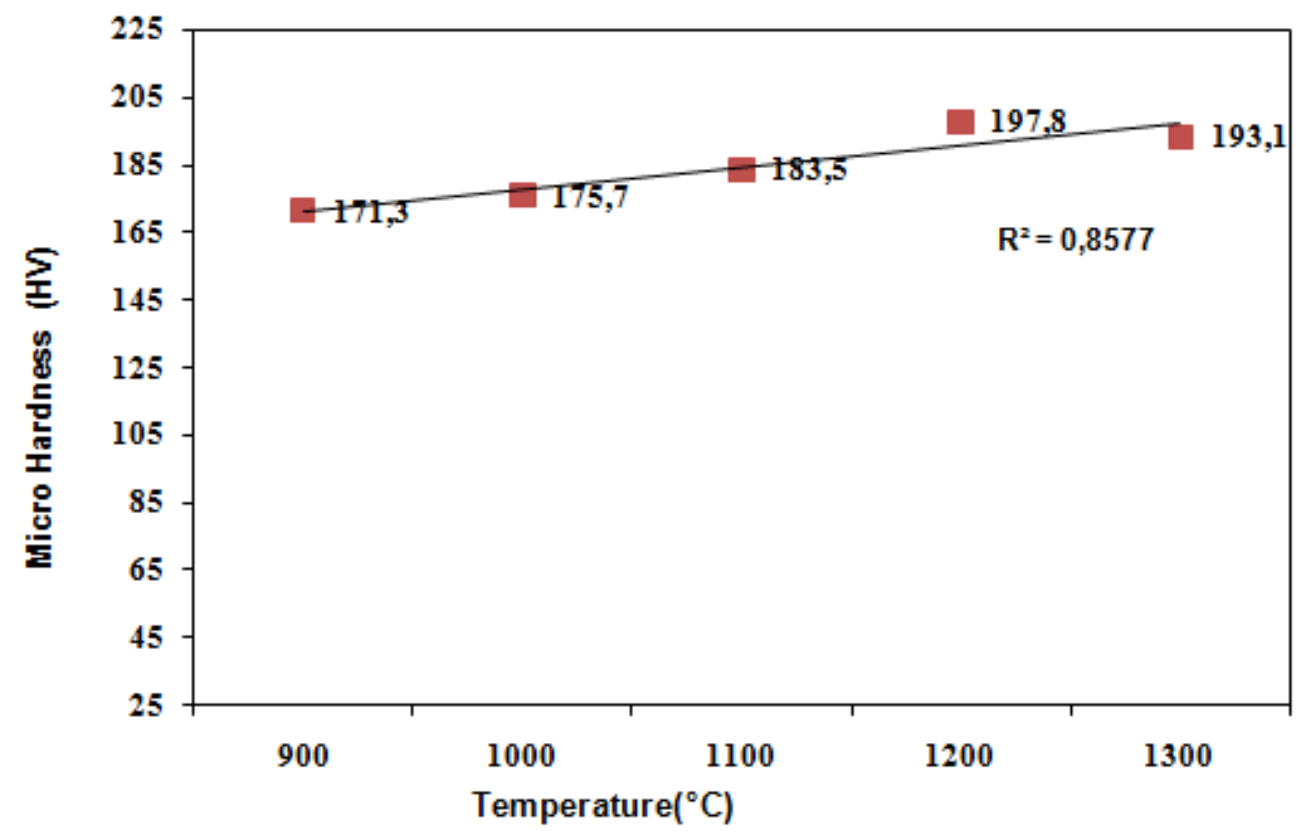

Figure 2. The Micro hardness change with respect to composition at Ti-10Cr-3,33Co-3,33 egg shelter powders.

\section{Metallographic Analysis}

Fig. 3 shows the SEM image of Ti-10Cr-3,33Co-3,33Organic waste composite produced by sintering at $900{ }^{\circ} \mathrm{C}$. Since the sintered sample is sintered at $900{ }^{\circ} \mathrm{C}$, it is seen that the bonding of the particles with the diffusion bond is not realized due to the low sintering temperature. 


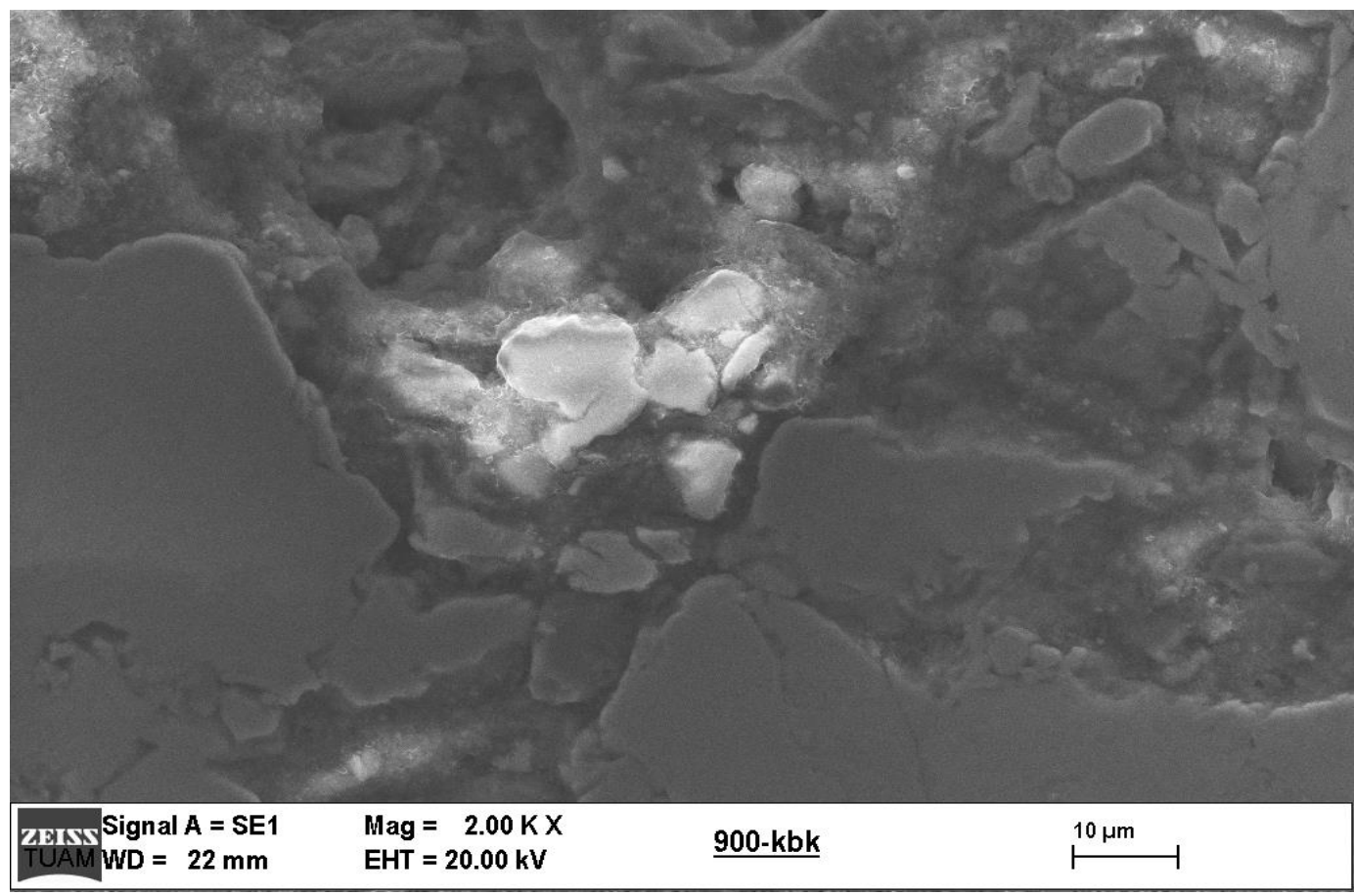

Figure 3. SEM view of Ti-10Cr-3,33Co-3,33 egg shelter composite at $900^{\circ} \mathrm{C}$

Figure 4 shows the SEM image of Ti-10Cr-3,33Co-3,33egg shelter composite produced by sintering at $1000{ }^{\circ} \mathrm{C}$. It is understood that a tighter bond between the particles is formed in the sample sintered at $1000^{\circ} \mathrm{C}$. The picture has been observed. The grain boundaries are not fully formed in the SEM image.

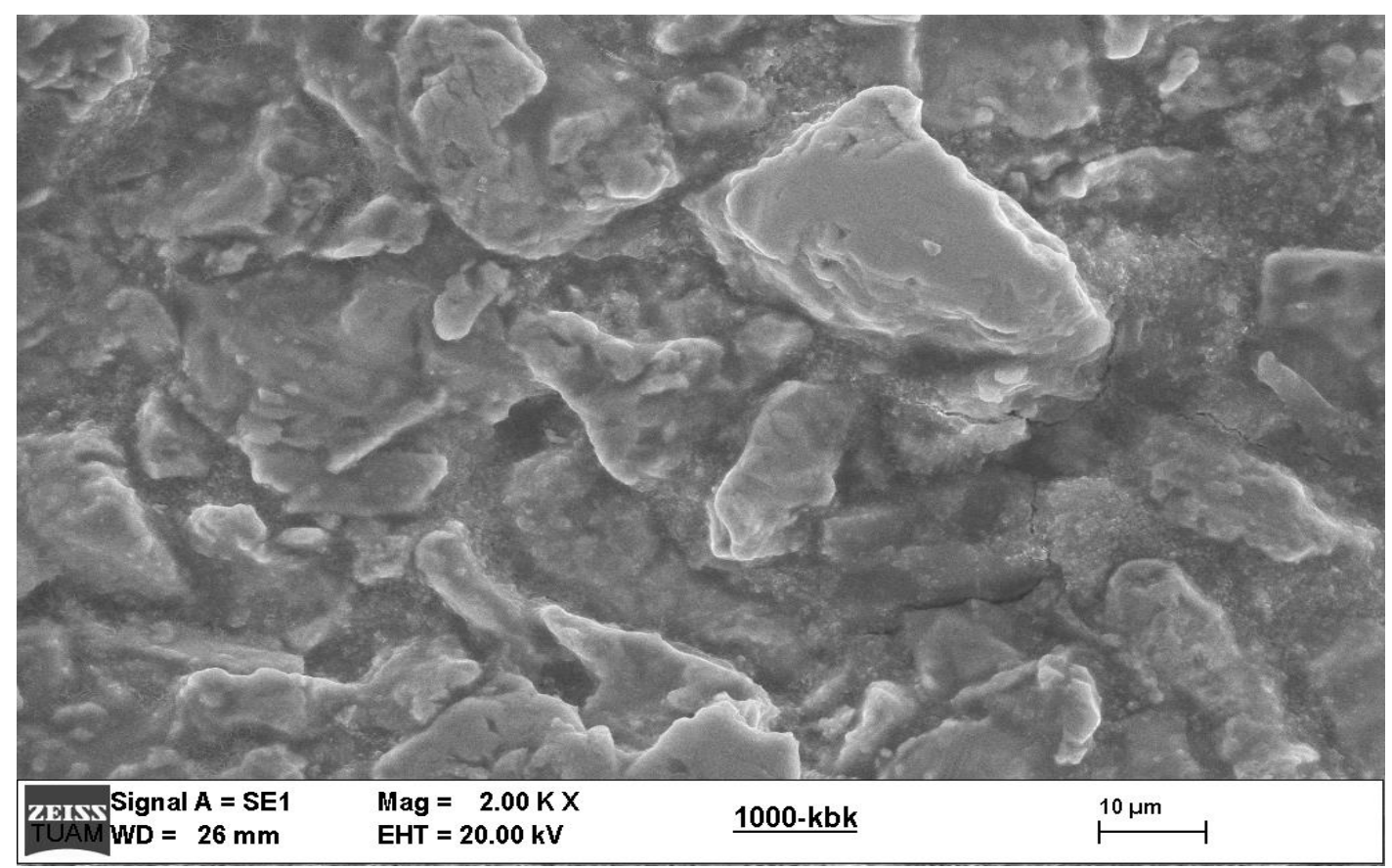

Figure 4. SEM view of Ti-10Cr-3,33Co-3,33egg shelter composite at $1000^{\circ} \mathrm{C}$

Fig.5 shows the SEM image of Ti-10Cr-3,33Co-3,33egg shelter composite produced by sintering at $1100{ }^{\circ} \mathrm{C}$. In the sample sintered at $1100{ }^{\circ} \mathrm{C}$, the porosity decreased further at $1000{ }^{\circ} \mathrm{C}$ compared to the sintered sample. The grain size and porosity were clearly observed in the SEM analysis image. 


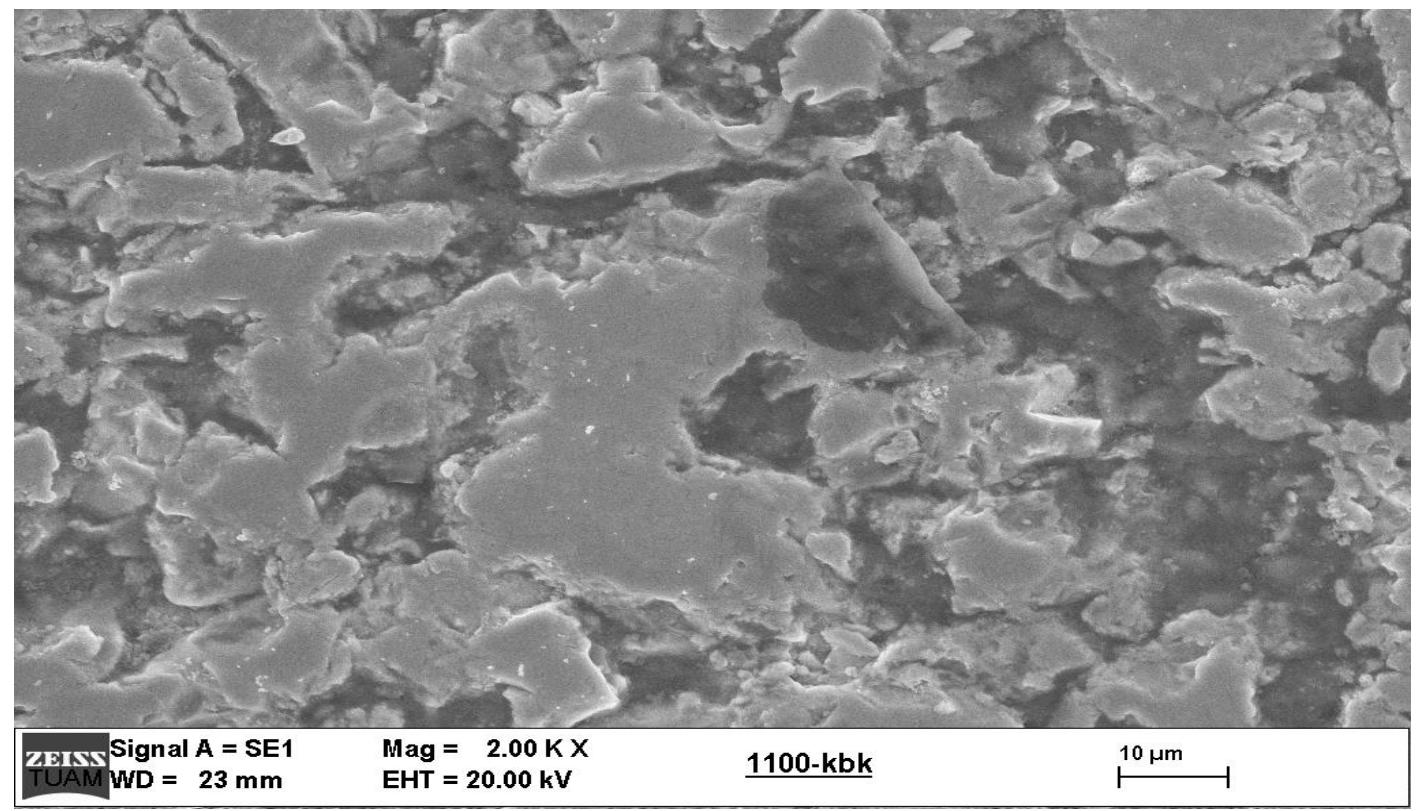

Figure 5. SEM view of Ti-10Cr-3,33Co-3,33egg shelter. composite at $1100^{\circ} \mathrm{C}$

Fig. 6 shows the SEM image of Ti-10Cr-3,33Co-3,33egg shelter composite produced by sintering at $1200{ }^{\circ} \mathrm{C}$. In the sample sintered at $1200{ }^{\circ} \mathrm{C}$, the porosity decreases even more at the lower temperatures compared to the sintered samples. The hardnes $\mathrm{s}$ measurements of the specimen produced at $1200^{\circ} \mathrm{C}$ confirm the porosity of the hardness increase.

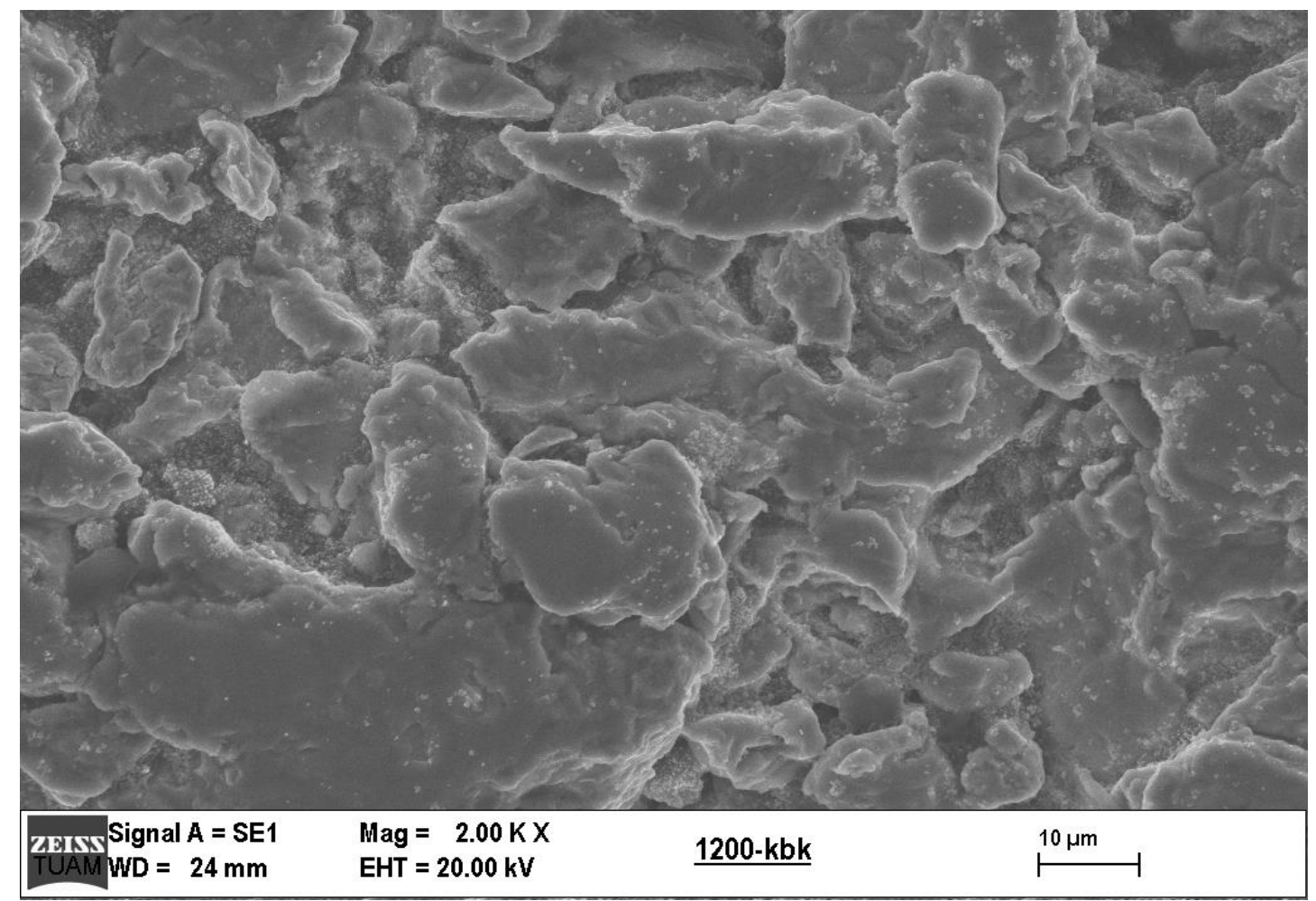

Figure 6. SEM view of Ti-10Cr-3,33Co-3,33egg shelter composite at $1200^{\circ} \mathrm{C}$

Figure 7 shows the SEM image of Ti-10Cr-3,33Co-3,33egg shelter composite produced by sintering at $1300{ }^{\circ} \mathrm{C}$. It is seen that the porosity decreases in the sample sintered at $1300^{\circ} \mathrm{C}$. In hardness measurements, it is observed that the hardness value of the sample produced at $1300^{\circ} \mathrm{C}$ decreased. 


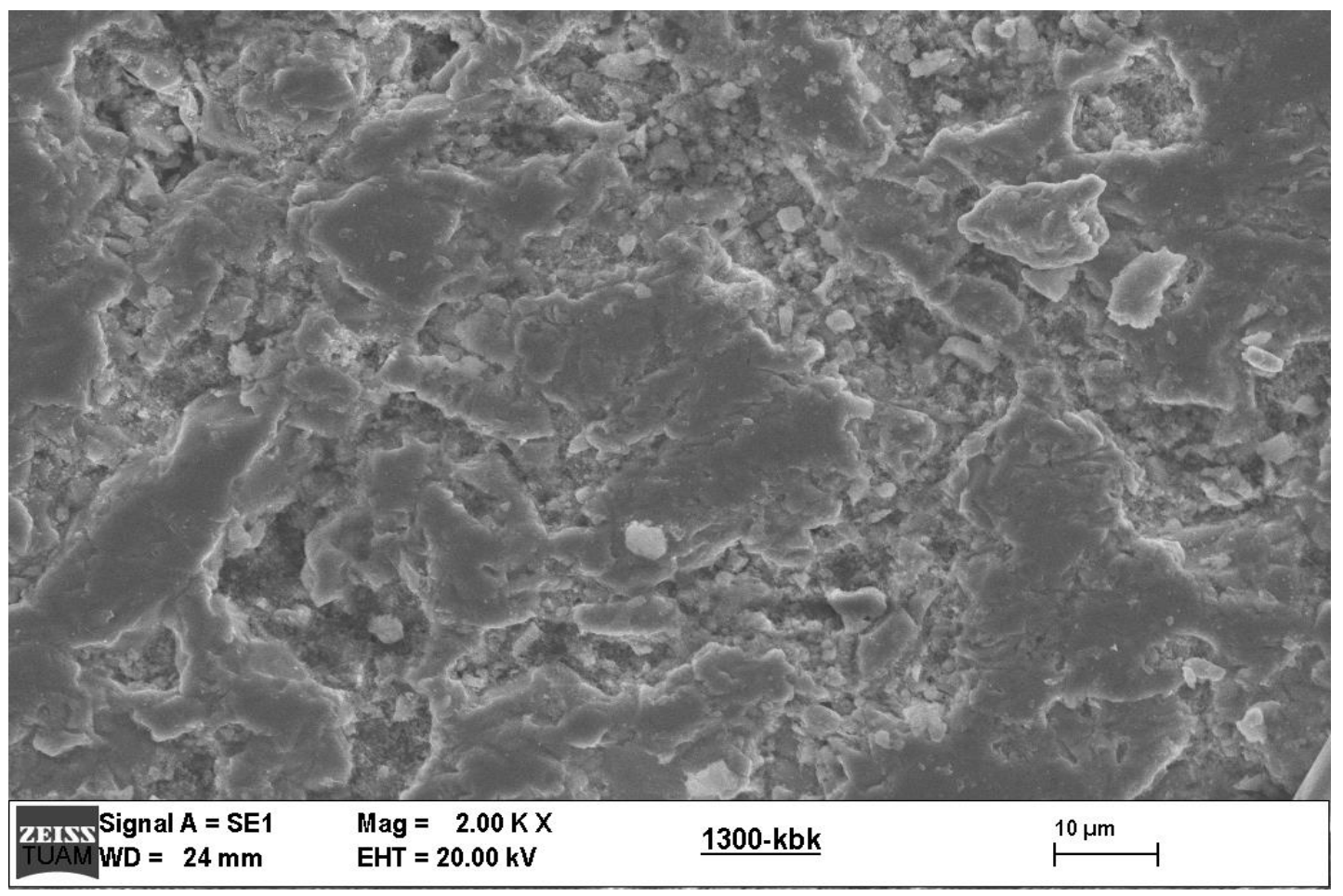

Figure 7. SEM view of Ti-10Cr-3,33Co-3,33egg shelter composite at $1300^{\circ} \mathrm{C}$

Ti-10Cr-3,33Co-3,33egg shelter composition specimens were produced by sintering at $900{ }^{\circ} \mathrm{C}$ with powder metallurgy. XRD analysis of the composite sample is given. According to the results, $\mathrm{Ti}, \mathrm{Cr}, \mathrm{Co}, \mathrm{Cr} 2 \mathrm{Ti}$, and $\mathrm{TiCr}$ phases are determined.

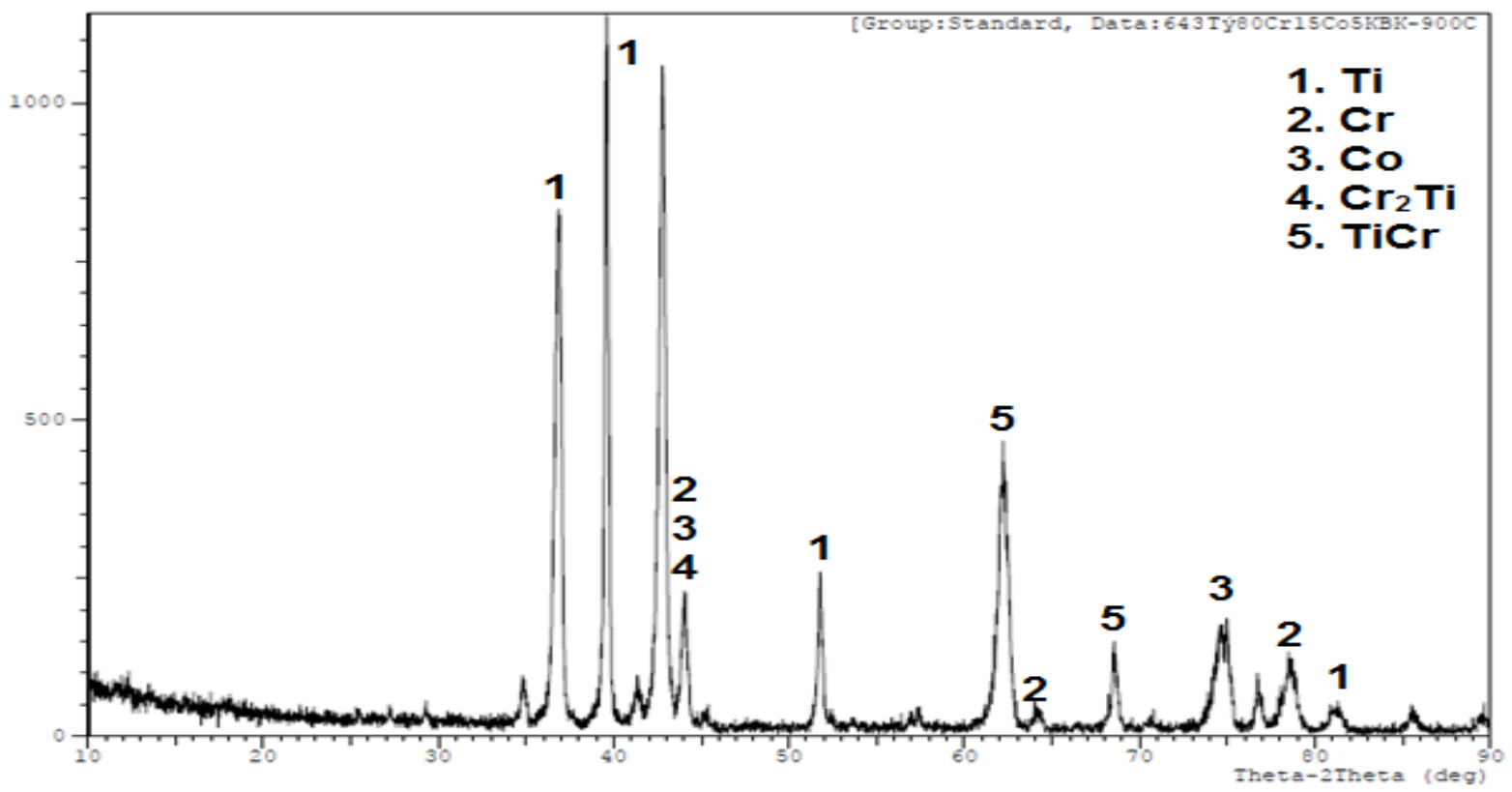

Figure 8. The XRD analysis results of Ti-10Cr-3,33Co-3,33egg shelter. composite at $900^{\circ} \mathrm{C}$

Ti-10Cr-3,33Co-3,33egg shelter is produced by sintering at $1300{ }^{\circ} \mathrm{C}$ with powder metallurgy. XRD analysis of the composite sample is given. According to the results, $\mathrm{Ti}, \mathrm{Cr}, \mathrm{Co}, \mathrm{Cr} 2 \mathrm{Ti}$, and $\mathrm{TiCr}$ phases are formed. It is observed that the same peaks occur at different intensities in the sample produced at $900{ }^{\circ} \mathrm{C}$. 


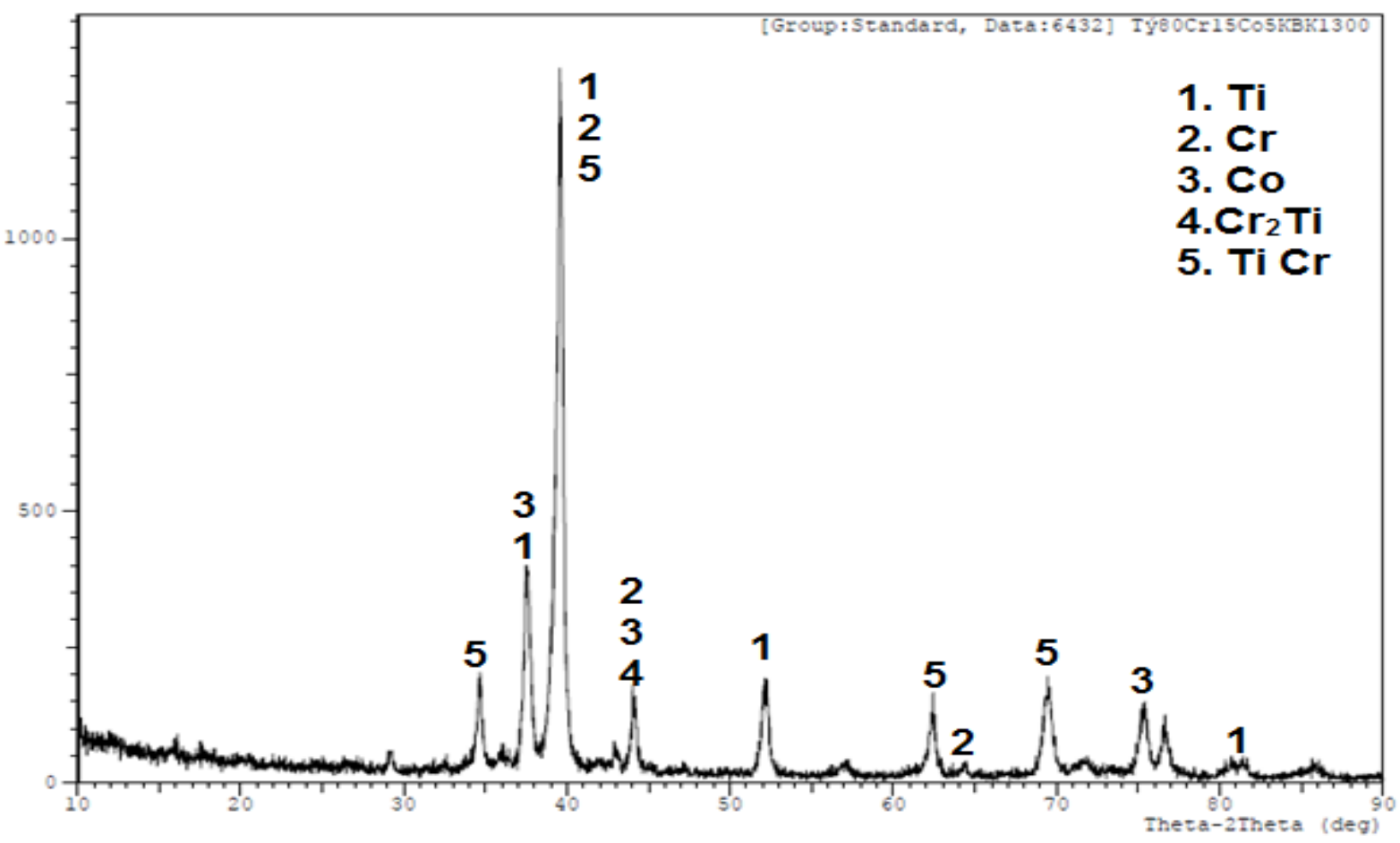

Figure 9. The XRD analysis results of Ti-10Cr-3,33Co-3,33egg shelter. composite at $1300^{\circ} \mathrm{C}$

\section{Conclusions}

Composites produced by electroless nickel plating technique show better mechanical properties besides sintering advantage. It is less porous than composites produced without coating. It is expected to increase corrosion resistance as it is less porous compared to composites produced without coating.

The results obtained from Ti-10Cr-3,33Co-3,33egg shelter composite samples are given below. It was aimed to increase the toughness and decrease the hardness value using eggshell powder in composite production.

-The highest density in composite made from Ti-10Cr-3,33Co-3,33 egg shelter powders sintered at range of $900^{\circ} \mathrm{C}-1300^{\circ} \mathrm{C}$ temperatures was obtained at $1200^{\circ} \mathrm{C}$. The highest density sample was found as $3,95 \mathrm{gr} / \mathrm{cm}^{3}$ at $1200^{\circ} \mathrm{C}$.

-The highest micro hardness was produced using the powder metallurgy method was found as $197,8 \mathrm{HV}$ at $1200^{\circ} \mathrm{C}$ in $\mathrm{Ti}-10 \mathrm{Cr}-$ 3,33Co-3,33 egg shelter composite samples.

-It was also found out the best properties at $1200^{\circ} \mathrm{C}$ in $\mathrm{Ti}-10 \mathrm{Cr}-3,33 \mathrm{Co}-3,33 \mathrm{Egg}$ shelter composite. It will be suitable for cutting or plotting tools used in soil industry.

\section{References}

Abdulrahman Idris, Tijani Hamzat Ibiyeye, Mohammed, Bashir Abubakar Haruna Saidu, Yusuf Hindatu, Mohammed Ndejiko Jibrin, and Mohammed Sulaiman (2014). "From Garbage to Biomaterials: An Overview on Egg Shell Based Hydroxyapatite" Hindawi Publishing Corporation Journal of Materials Volume 2014

Boonpoke A., Chiarakorn S., Laosiripojana N., Towprayoon S., and Chidthaisong A., (2013). "Synthesis of activated carbon andMCM- 41 frombagasse and rice husk and their carbon dioxide adsorption capacity," Journal of Sustainable Energy\&Environment, vol. 2, pp. 77-81.

Boron, L., (2004). Citrato de cálcio da casca do ovo: biodisponibilidade e uso como suplemento alimentar. UFSC, Florianópolis.

Luengo M. Martin, Yates M., Ramos M. et al., (2011). "Renewable raw materials for advanced applications," in Proceedings of the World Congress on Sustainable Technologies (WCST'11), pp. 19-22, IEEE.

Neves, M.A., (1998). Alternativas para valorização da casca de ovo como complemento alimentar e em implantes ósseos. UFSC, Florianópolis.

Rashidi N. A., Yusup S., Ahmad M.M., Mohamed N.M., and Hameed B. H.,(2012) "Activated carbon from the renewable agricultural residues using single step physical activation: a preliminary analysis,” APCBEE Procedia, vol. 3, pp. 84-92,. 
Ling I. H. and Teo D. C. L., (2011) "Lightweight concrete bricks produced from industrial and agricultural solid waste," in Proceedings of the World Congress on Sustainable Technologies

(WCST'11), pp. 148-152,.

Peng G. Y., Fang Y. S., Zhe Z. J., Chen W. Z., and Yu Z. M.,( 2000) "Preparation of active carbon with high specific surface srea fromrice husks," Chemical Research in Chinese Universities, vol. 3,

Surip S. N., Bonnia N. N., Anuar H., Hassan N. A., and Yusof, N.M., (2012)"Nanofibers from oil palm trunk (OPT): preparation \& chemical analysis," in Proceedings of the IEEE Symposium on Business, Engineering and Industrial Applications (ISBELA '12), pp. 809-812, Bandung, Indonesia.

Taheri-Nassaj, E., Mirhosseini, S.H., “An In Situ WC-Ni Composite Fabricated By The SHS Method”, Journal Of Materials Processing Technology, Volume: 142, 422-426, 2003.

Upadhyaya G.S., Bhaumik S.K., (1998).Sintering Of Submicron WC-10\% Co Hard Metals Containing Ni And Fe, Materyal Sciences Engineering-A, Volume:249, 105-106.

Xu Z., Zhu Y., Liang M., Zhang H., and Liu H.,(2011) “Optimization of the preparation conditions for activated carbons from sugarcane bagasse an agricultural waste," in Proceedings of the International Conference on Computer Distributed Control and Intelligent Environmental Monitoring (CDCIEM '11), pp. 555- 559, IEEE,.

Yönetken A., Bilici Ö.V., Erol A., (2019). Ti-Cr-Cokompozit Malzemelerin Poisson Oranı, Sertliği ve Elastik Modülleri Arasındaki Korelasyon, Afyon Kocatepe Üniversitesi Fen ve Mühendislik Bilimleri Dergisi, AKÜ FEMÜBİD 19, Özel Say1 404-409

Yuhong X., Ki L., Xiaoying Z., Schoenung Julie M.,( 2008) “A Streamlined Life Cycle Assessment On The Fabrication Of WCCo Cermets" Journal Of Cleaner Production, Volume:16, 1118-1126,

Zakaria Z., Buniran S., and Ishak M. I., (2010) "Nanopores activated carbon rice husk," in Proceedings of the International Conference on Enabling Science and Nanotechnology (ESciNano '10), pp. 1-2, Kuala Lumpur, Malaysia, December. 